\title{
'SCS425 Luiza': new apple cultivar with medium chilling requirement and resistant to glomerella leaf spot (colletotrichum spp.)
}

\author{
Frederico Denardi ${ }^{1}$, Marcus Vinícius Kvitschal ${ }^{2}$, Maraisa Crestani Hawerroth ${ }^{3}$, Luiz Carlos Argenta ${ }^{4}$
}

Abstract- Apple is one of the main agribusiness products of temperate-zone fruits in Southern Brazil. More than $90 \%$ of apple production is obtained from only two apple cultivars - Gala and Fuji and their mutations. These apple varieties are insufficiently adapted to the regional climate and 'Gala' and its mutations are also susceptible to glomerella leaf spot-GLS, currently the main apple disease in Brazil. 'SCS425 Luiza' cultivar was developed by Epagri / Estação Experimental Caçador, aiming to offer to the production chain an early apple variety better adapted to the environmental conditions of Southern Brazil and resistant to GLS. 'SCS425 Luiza' cultivar was obtained by artificial hybridization carried out in 2001 using the cultivars Imperatriz and Cripps Pink as parents. 'SCS425 Luiza' has lower chilling requirement compared to 'Galaxy', higher flowering precocity and yield potential at least equivalent to 'Galaxy'. It produces fruits with skin finish, flavor and flesh texture adequate for the Brazilian market and storability similar to 'Galaxy' apples when harvested at the same maturity.

Index terms: Malus $x$ domestica, breed apple variety, climatic adaptation, fruit quality.

\section{'SCS 425 Luiza': nova cultivar de macieira de médio requerimento de frio hibernal e resistente à mancha foliar de glomerella (collectorichum spp.)}

Corresponding author: denardi.frederico@gmail.com

Received: February 14, 2018 Accepted: July 13, 2018.

Copyright: All the contents of this journal, except where otherwise noted, is licensed under a Creative Commons Attribution License.
Resumo- A maçã é um dos principais produtos do agronegócio da fruticultura temperada do Sul do Brasil. Mais de $90 \%$ da produção são originadas com o cultivo de apenas duas cultivares Gala e Fuji, e seus mutantes. Essas cultivares são pouco adaptadas ao clima regional, sendo as do grupo 'Gala' também suscetíveis à doença mancha foliar de glomerella - MFG, atualmente a principal doença da macieira no Brasil. A 'SCS425 Luiza' foi desenvolvida pela Epagri / Estação Experimental de Caçador, buscando disponibilizar à cadeia produtiva mais uma cultivar de macieira precoce, mais bem adaptada aos ambientes de cultivo sul-brasileiros e resistente à MFG. Foi obtida via hibridação artificial, realizada em 2001, tendo como parentais as cultivares Imperatriz e Cripps Pink. A 'SCS425 Luiza' apresenta menor requerimento em frio hibernal que a 'Galaxy', tem maior precocidade em iniciar a floração e possui produção ao menos similar à da 'Galaxy'. Produz frutos com qualidade visual, sabor e textura de polpa adequados para o mercado brasileiro e com capacidade de conservação similar à 'Galaxy' quando colhida no mesmo estágio de maturação. Termos para indexação: Malus $x$ domestica, cultivar melhorada, adaptação climática, qualidade de frutos.

\section{$(\mathrm{cc}) \mathrm{EY}$}

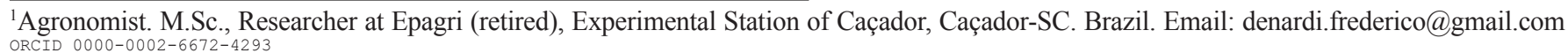

${ }^{2}$ Agronomist. D.Sc., Researcher at Epagri, Experimental Station of Caçador. Caçador-SC. Brasil. Email: marcusvinicius@epagri.sc.gov.br ORCID 0000-0001-6161-3546

${ }^{3}$ Agronomist. D.Sc., Researcher at Epagri, Experimental Station of Caçador, Caçador-SC. Brasil. Email: maraisahawerroth@epagri.sc.gov.br ORCID 0000-0002-5428-0744

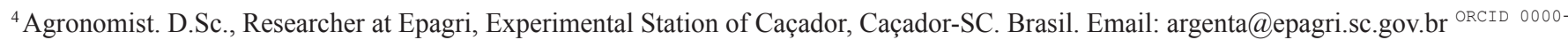
0001-9614-0523
} 
Apple cultivation, although relatively recent in commercial scale in Brazil, represents the second most important fruit of temperate climate, being the second most consumed fruit in Brazil (CNA, 2011). In the 2013/2014 harvest, the State of Santa Catarina contributed with 629 thousand tons of apples produced in 17,762 ha, representing about $46 \%$ of all Brazilian production (VIEIRA, GOULART JUNIOR, 2014). However, the profit margin of producers has reduced in the last decades, as a reflection of the increase of production costs in relation to selling prices (FIORAVANÇO; LAZZAROTTO, 2012).

The poor availability of commercial cultivar options is among the limitations of the Brazilian apple production chain, with predominance of Gala and Fuji clones (KVITSCHAL; DENARDI, 2011; FIORAVANÇO; LAZZAROTTO, 2012). The cultivation of the 'Gala' cultivar and its mutant clones stands out, whose fruit represents $55 \%$ of the total stored in cold chambers and marketed throughout the year, which are reference in flavor and therefore highly appreciated and preferred by many Brazilian consumers (MAPA, 2014). However, 'Gala' clones present important limitations to the productive chain of Southern Brazil, with emphasis on climate adaptation and phytosanitary issues.

Commercially available 'Gala' clones are susceptible to numerous diseases, such as glomerella leaf spot - GLS (Colletotrichum spp), whose control requires special care by the producer, with the excessive use of fungicides for their control (GONZÁLEZ et al., 2006; VELHO et al., 2015). Thus, the chemical control of diseases represents one of the main items of the apple production costs in Southern Brazil, with potential damaging effects on the agroecossystem and consumers' health (PETRI et al., 2011). Therefore, the exploitation of apple genotypes presenting genetic resistance to the main diseases represents an opportunity to reduce production costs, provide greater food security and expectations of broad consumer acceptance due to the lower potential environmental impact.

Imported cultivars grown in colder countries, such as Gala and Fuji and their colored clones, do not present satisfactory climatic adaptation in most Brazilian apple growing regions (PETRI et al., 2011). According to HAWERROTH et al. (2010), the use of sprouting inducers to overcome the dormancy of buds is efficient in compensating the lack of chilling in these cultivars. However, this is another item responsible for the increase in the apple production costs in Brazil, associated with the potential harmful effects inherent in the use of agrochemicals.

In terms of fruit acceptance as a function of quality, the majority of consumers prefer apples with high pulp firmness ( $\geq 14 \mathrm{lb}$ ) and high sugar content (HARKER et al., 2008). The authors also report that apples with pulp firmness less than $12 \mathrm{lb}$ are considered farinaceous, with low juiciness and crispness, and are usually rejected by consumers. Therefore, the storability of apples is usually associated with the time between harvest and the date when fruits reach $12 \mathrm{lb}$ of firmness and / or high rot rates or physiological disturbance.

Therefore, the development and availability of new apple cultivars better adapted to the different growing environments of Southern Brazil, resistant to the main diseases and with high quality standard, represent the main focus of the Apple Breeding Program carried out at Epagri (DENARDI et al., 2013, KVITSCHAL et al., 2013).

Epagri developed the 'SCS425 Luiza' cultivar in order to provide the productive sector another option of early apple cultivar, better adapted to the climatic conditions of Southern Brazil, resistant to GLS, producing fruits with high visual and taste quality, adequate to the Brazilian consumer market.

'SCS425 Luiza' apple cultivar was originated from the controlled hybridization between 'Imperatriz' $(+\rightarrow)$ and 'Cripps Pink' (Pink Lady $\left.{ }^{\mathrm{TM}}\right)(\widehat{\jmath})$ cultivars and via successive cycles of mass selection (Figure 1). It is the result of a selection process that prioritized the medium chilling requirement and resistance to GLS (Colletotrichum spp), characteristics inherited from the 'Imperatriz' parent, and the high visual and organoleptic quality of fruits, transmitted by the 'Cripps Pink' parent.

With the accomplishment of controlled crosses in the year of 2001, 602 hybrid plants were obtained, which were developed in greenhouse for one vegetative cycle and later transplanted to field nursery. In the nursery, plants were submitted to a pre-selection process aiming low degree of juvenility (few thorns in the stem), high plant vigor and some resistance to powdery mildew (Podosphaera leucotricha), resulting in the pre-selection of 232 hybrid plants. Resistance to powdery mildew was visually evaluated on a numerical scale ranging from 1 to 5 , selecting only plants with scores 4 and 5 (symptoms in only a few completely expanded leaves or absence of symptoms). Individuals preselected in this phase were grafted on M-9 rootstock for evaluation of sprouting capacity, resistance to diseases such as apple scab (Venturia inaequalis) and GLS, fruit set and fruit quality, each individual being represented by one plant in experimental orchard installed at the Epagri Experimental Station of Caçador, SC, whose evaluations were carried out between 2004 and 2009. The plant that originated 'SCS425 Luiza' cultivar was selected in 2007 and identified by experimental code M-15/07.

Evaluations regarding sprouting capacity, precocity in beginning flowering and fruiting, and fruit quality were conducted according to methodology described in DENARDI et al. (2013). The evaluation of resistance to GLS was performed in January 2010, via artificial inoculation in a specific climatic chamber, according to methodology described by FURLAN et al. (2010), using 
Galaxy cultivar as susceptible standard.

The genotypes that stood out for the agronomic characteristics of interest and reaction to diseases were multiplied on G.814 commercial rootstock and submitted to advanced evaluations at the Epagri / Experimental Station of Caçador, located in Caçador-SC, and in an experiment conducted in Fraiburgo-SC (27 $03^{\prime}$ ' 47 " $S$ and $50^{\circ} 52^{\prime} 54^{\prime \prime} \mathrm{W}, 1047 \mathrm{~m}$ a.s.1.), the main apple producing region in mid-eastern Santa Catarina.

In Fraiburgo-SC, evaluations were carried out during the 2009/2010 to 2014/2015 harvest seasons in a randomized block design with four replicates, composed of four plants per plot, at density of 1,667 plants per hectare (spacing of $1.5 \mathrm{~m}$ between plants and $4.0 \mathrm{~m}$ between rows), totaling 12 treatments, using 'Galaxy' and 'Fuji Suprema' commercial cultivars as controls. In this phase, plant vigor (indirect evaluation by determination of the trunk cross-section area), sprouting capacity, shoot phenology, flowering and fruit ripening, yield and average fruit mass were evaluated according to methodology described in DENARDI et al. (2013). Fruits picked in the 2012/2013 harvest season were evaluated for preservation in controlled atmosphere (CA) and regular air atmosphere (RA) at $0.7^{\circ} \mathrm{C}$, and physicochemical flesh analyses were carried out according to methodology described in SCOLARO et al. (2015).

Considering the performance in relation to the trunk cross-sectional area (TCSA) as an indirect measure of plant vigor, 'SCS425 Luiza' was more vigorous in relation to 'Galaxy' and 'Fuji Suprema' controls in the 2012/2013 harvest season, in an experiment conducted in Fraiburgo-SC (Table 1).

Characteristically, fruiting in 'SCS425 Luiza' plants occurs predominantly in spur buds, with dense formation of flowering buds along branches, resulting in very intense flowering. Branch evaluations of two-year-old plants (young plants still in formation) showed more intense floral structures in comparison to 'Galaxy' and 'Fuji Suprema' controls, indicating greater precocity to start fruiting. This is also evidenced by observing production data for the first harvest (2011/2012), whose mean was significantly higher in 'SCS425 Luiza' compared to 'Galaxy' and 'Fuji Suprema' controls (Table 1). This characteristic contributes to a faster return on capital initially invested in the implementation of orchards, as well as to the higher production accumulated over the years.

'SCS425 Luiza' cultivar stands out for its high fruit production, with average and cumulative production equivalent to 'Galaxy' and 'Fuji Suprema', considering the performance in four consecutive harvest seasons, in an experiment conducted in Fraiburgo-SC (Table 1). Analyzing the performance of the 'SCS425 Luiza' cultivar in each harvest season, the importance of fruit thinning at the appropriate time and intensity is emphasized, in order to avoid the occurrence of biennual flowering. Considering the experimental nature of the study, the thinning procedure in this trial was performed according to recommendation for 'Galaxy' and 'Fuji Suprema' controls. However, the variation in fruit production throughout the seasons suggests that 'SCS425 Luiza' requires a more intense fruit thinning than is commonly performed, at least in the first years after the beginning of production, indicating the need for specific studies to develop adequate technical thinning recommendation for 'SCS425 Luiza' cultivar. Additionally, it has been observed that 'SCS425 Luiza' shows deficiencies in the renewal of older flower spur buds. This characteristic indicates the need to adopt procedures aimed at the constant renewal of fruiting structures, under the risk of plants entering into an early decline, with the consequent declining production in the orchard.

'SCS425 Luiza' cultivar has genetic resistance to GLS, since the symptoms of this disease were not identified in plants after artificial inoculation nor in field evaluations carried out during the entire development period of the new cultivar. This characteristic results in lower production cost for the phytosanitary control of orchards in relation to susceptible cultivars, such as 'Galaxy' and its colored clones. In addition, 'SCS425 Luiza' cultivar exhibits moderate resistance to powdery mildew, but is moderately susceptible to apple scab.

It is suggested that 'SCS425 Luiza' presents lower chilling requirement than 'Galaxy', since there is tendency of budding and flowering around a week before, with more intense and uniform sprouting up.

The ripening of 'SCS425 Luiza' apple fruit occurs at the end of January until the beginning of February near that of 'Galaxy' apple fruit, in the mid-western Santa Catarina, Fruits are red-striped, characteristically darker than 'Galaxy' fruits, with a bicolor pattern on a whitish yellow background, and without 'russeting'. Fruits have rounded-conical shape and with a very uniform size, possibly due to the adequate adaptation to the culture environments of mid-western Santa Catarina. Fruits have average mass of $135.0 \mathrm{~g}$, which is intermediate between 'Galaxy' and 'Fuji Suprema' fruits. The flesh of 'SCS425 Luiza' apple fruit is white-cream, very crispy and juicy.

When assessing the quality indices of 'SCS425 Luiza' apples in relation to 'Galaxy' apples harvested in the 2012/2013 harvest season and stored in different types of atmosphere in the 6-month period, it was found that the storage potential of 'SCS425 Luiza' and 'Galaxy' apple fruits were equivalent (Figure 2 and Table 2).

The higher starch degradation rate at harvest indicates that 'SCS425 Luiza' apples were at a more advanced maturation stage than Galaxy apples, although they had higher flesh firmness and titratable acidity, and these differences were maintained after storage (Table 2). During the six months of storage, 'SCS425 Luiza' apples 
presented higher average soluble solids content compared to 'Galaxy' apples. The storage potential of apples is usually associated with the time between the harvesting date and the storage period in which fruits reach firmness of $12 \mathrm{lb}$ and / or high rot rates or physiological disorders (HARKER et al., 2002; 2003). As a result, fruit rejection by consumers due to the reduction of sugar content is maximal when the soluble solids content is less than $12 \%$ (HARKER et al., 2002; 2003). The results observed in this evaluation indicate that the storage potential of 'SCS425 Luiza' apple fruits harvested with flesh firmness of approximately $17 \mathrm{lb}$ is approximately 2 and 6 months when stored under regular air atmosphere (RA) or controlled atmosphere (CA), respectively. When harvested with flesh firmness higher than that of Galaxy apples, 'SCS425 Luiza' apples can be stored for a comparatively longer time depending on the potential to reach minimum firmness of $12 \mathrm{lb}$.

Although apple trees have hermaphrodite flowers, they generally require cross-pollination for producing good-quality fruits due to the occurrence of gametophytic self-incompatibility (HEGEDÜS, 2006). In trials aiming to evaluate pollinating plants for 'SCS425 Luiza' conducted at the Epagri Experimental Station of Caçador, SC, 'SCS426 Venice' and 'SCS433 Felix 3' and 'SCS431 Felix 1' wild cultivars (experimental codes 140 / 191 and $140 / 228$, respectively) can be efficiently used as pollinators in 'SCS425 Luiza' commercial orchards (HAWERROTH et al., 2015) due to the coincidence of flowering period and genetic compatibility. It is indicated the use of more than one pollinating cultivar in the orchard, being the pollination pressure at least $15 \%$ of plants in the orchard. The orchard design using alternate rows of 'SCS425 Luiza' with 'SCS426 Venice' can be used as well, in which case there is no need for the use of another pollinating cultivar.

As it is a cultivar protected by Epagri with the SNPC / MAPA (National Service of Cultivar Protection / Ministry of Agriculture, Livestock and Supply), 'SCS425 Luiza' young trees and their pollinators must be directly purchased from licensed nursery authorized by Epagri. For further information, interested parties should contact the team of breeders at Epagri - Experimental Station of Caçador.

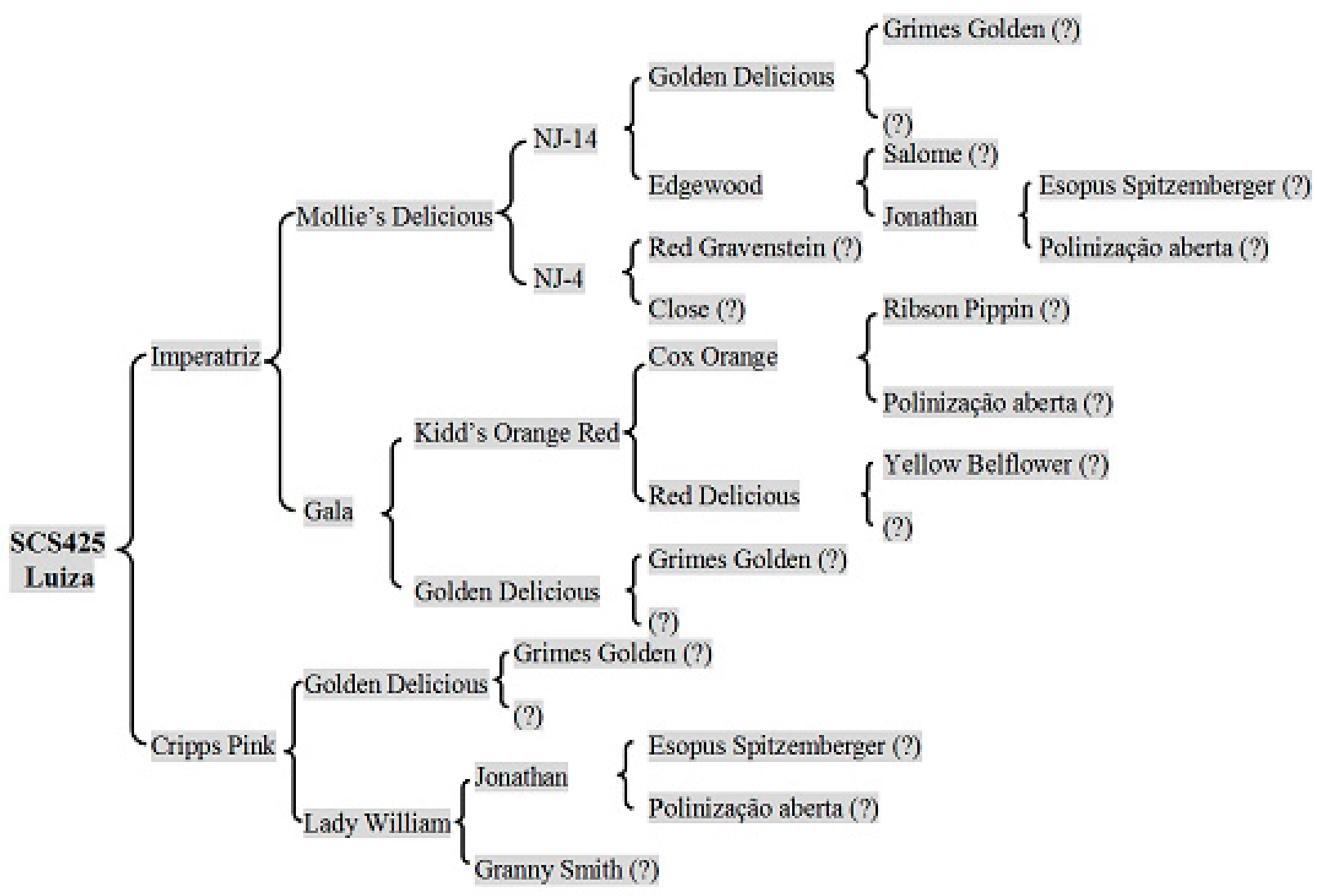

Figure 1. Genealogy of 'SCS425 Luiza' apple cultivar. The question mark (?) refers to the lack of information in literature about parents. 
Table 1. Performance of 'SCS425 Luiza' apple cultivar in relation to 'Fuji Suprema' and 'Galaxy' controls cultivated on G.814 semidwarfing rootstock, in an experiment conducted in the city of Fraiburgo-SC, in six harvest seasons (2009/2010 to 2014/2015).

\begin{tabular}{|c|c|c|c|c|c|c|c|c|c|}
\hline \multirow{3}{*}{$\begin{array}{c}\text { Genotype } \\
\text { SCS425 Luiza }\end{array}$} & \multirow[b]{2}{*}{$\begin{array}{c}\mathrm{TCSA}^{1} \\
\left(\mathrm{~cm}^{2}\right)\end{array}$} & \multicolumn{7}{|c|}{ Production $\left(\mathrm{t} \mathrm{ha}^{-1}\right)^{*}$} & \multirow[b]{2}{*}{$\begin{array}{l}\text { Average } \\
\text { fruit } \\
\text { mass }(g)\end{array}$} \\
\hline & & \multicolumn{2}{|c|}{$2011 / 2012 \quad 2012 / 2013$} & \multirow{2}{*}{$\begin{array}{l}2013 / 2014 \\
\text { A } 62.78 \mathrm{a}\end{array}$} & \multirow{2}{*}{$\begin{array}{l}2014 / 2015 \\
\text { B } 22.22 \text { b }\end{array}$} & \multicolumn{3}{|c|}{$\begin{array}{cc}\text { Cumulative } & \text { Average } \\
\text { production } & \text { annual } \\
(4 \text { harvest seasons) production }\end{array}$} & \\
\hline & $18.47 \mathrm{a}$ & B 28.33 a B 2 & $25.56 \mathrm{a}$ & & & & $39.47 \mathrm{a}$ & $34,87 \mathrm{a}$ & $135,03 \mathrm{~d}$ \\
\hline Galaxy & $10.68 \mathrm{c}$ & B 8.89 b $\quad$ B 2 & $23.33 \mathrm{a}$ & B $21.67 \mathrm{~b}$ & A $48.33 \mathrm{a}$ & & $00.98 \mathrm{a}$ & $25,24 \mathrm{a}$ & $121,44 \mathrm{e}$ \\
\hline Fuji Suprema & $14.92 \mathrm{~b}$ & $\mathrm{~B} \quad 9.44 \mathrm{~b} \quad \mathrm{~A} 2^{2}$ & $26.11 \mathrm{a}$ & A $18.33 \mathrm{~b}$ & A $41.67 \mathrm{a}$ & & $94.13 \mathrm{a}$ & $23,53 \mathrm{a}$ & $152,74 \mathrm{c}$ \\
\hline \multirow[b]{2}{*}{ Genotype } & \multirow{2}{*}{\multicolumn{2}{|c|}{$\begin{array}{l}\text { Flowering period } \\
\text { (beginning to full) }\end{array}$}} & \multirow{2}{*}{\multicolumn{2}{|c|}{$\begin{array}{l}\text { Fruit ripening } \\
\text { (beginning) }\end{array}$}} & \multirow{2}{*}{$\begin{array}{l}\text { Sprouting } \\
\text { capacity in } \\
\text { mid-western } \\
\mathrm{SC}^{2}\end{array}$} & \multicolumn{4}{|c|}{ Disease resistance $^{3}$} \\
\hline & & & & & & Scab & $\begin{array}{l}\text { Powdery } \\
\text { mildew }\end{array}$ & $\mathrm{GLS}^{4}$ & Fruit rots \\
\hline SCS425 Luiza & $\begin{array}{l}2 \mathrm{nd} \\
\text { Septen } \\
10 \text { days }\end{array}$ & $\begin{array}{l}\text { d } 10 \text { days of } \\
\text { mber to the } 3 \mathrm{rd} \\
\text { s of September }\end{array}$ & $\begin{array}{c}\text { 3rd } \\
\text { Janua } \\
10 \text { days }\end{array}$ & $\begin{array}{l}10 \text { days of } \\
\text { ry to the } 1 \text { st } \\
\text { of February }\end{array}$ & 4.5 & MS & MR & $\mathrm{R}$ & MR \\
\hline Galaxy & $\begin{array}{r}3 \mathrm{rd} \\
\text { Septen } \\
10 \mathrm{da}\end{array}$ & $\begin{array}{l}10 \text { days of } \\
\text { mber to the } 1 \mathrm{st} \\
\text { ys of October }\end{array}$ & $\begin{array}{c}3 \mathrm{rd} \\
\text { Janua } \\
10 \text { day }\end{array}$ & $\begin{array}{l}10 \text { days of } \\
\text { ry to the } 1 \text { st } \\
\text { sof February }\end{array}$ & 3.5 & $\mathrm{~S}$ & $\mathrm{~S}$ & $\mathrm{~S}$ & $\mathrm{~S}$ \\
\hline Fuji Suprema & $\begin{array}{r}2 \mathrm{nd} \\
\text { Septen } \\
10 \mathrm{da}\end{array}$ & $\begin{array}{l}10 \text { days of } \\
\text { mber to the } 1 \text { st } \\
\text { ays of October }\end{array}$ & $\begin{array}{r}2 \mathrm{nd} \\
\mathrm{o}\end{array}$ & $\begin{array}{l}\text { fortnight } \\
\text { f March }\end{array}$ & 3.5 & $\mathrm{~S}$ & MR & $\mathrm{R}$ & $\mathrm{S}$ \\
\hline
\end{tabular}

${ }^{1}$ Cross-sectional area of the stem measured at $5 \mathrm{~cm}$ above the grafting point in the 2012/2013 harvest season. * Averages followed by the same capital letter in the row and lower-case letter in the column do not differ from each other by the Scott-Knott test at $5 \%$ error probability. ${ }^{2}$ Numerical scale, where 1 corresponds to the sprouting of the apical buds of branches, and 5 represents the sprouting of all buds (vegetative and floriferous), in response to treatment to overcome the dormancy of buds with $3.5 \%$ mineral oil and $0.3 \%$ hydrogenated cyanamide. ${ }^{3} \mathrm{R}$ : resistant; MR: moderately resistant; MS: moderately susceptible; $\mathrm{S}=$ susceptible. ${ }^{4} \mathrm{GLS}$ : glomerella leaf spot.

Table 2. Starch index, flesh firmness, titratable acidity and soluble solids content of 'SCS425 Luiza' and 'Galaxy' apples one day after harvest and after storage (mean of 0,2, 4 and 6 months of storage) in controlled atmosphere and regular air atmosphere.

\begin{tabular}{|c|c|c|c|c|c|}
\hline \multirow{2}{*}{ Cultivar } & Starch index ${ }^{1}$ & Fleshfirmness & $\begin{array}{l}\text { Soluble solids } \\
\text { content (SSC) }\end{array}$ & $\begin{array}{l}\text { Titratable } \\
\text { acidity }\end{array}$ & $\begin{array}{l}\mathrm{SSC} / \text { titratable } \\
\text { acidity ratio }^{2}\end{array}$ \\
\hline & - 1-9 scale - & --- Lb --- & ------ \% ------ & ------ \% ------- & -------------- \\
\hline & \multicolumn{5}{|c|}{ One day after harvest } \\
\hline SCS425 Luiza & $5.9 \mathrm{a}$ & $17.3 \mathrm{a}$ & $13.1 \mathrm{a}$ & $0.507 \mathrm{a}$ & 25.8 \\
\hline \multirow[t]{2}{*}{ Galaxy } & $4.5 \mathrm{~b}$ & $16.6 \mathrm{~b}$ & $12.6 \mathrm{a}$ & $0.409 \mathrm{~b}$ & 30.8 \\
\hline & \multicolumn{5}{|c|}{ Averages of $0-6$ months of storage } \\
\hline SCS425 Luiza & -- & $14.3 \mathrm{a}$ & $13.6 \mathrm{a}$ & $0.401 \mathrm{a}$ & 33.9 \\
\hline Galaxy & -- & $13.1 \mathrm{~b}$ & $12.8 \mathrm{~b}$ & $0.332 \mathrm{~b}$ & 38.5 \\
\hline
\end{tabular}

Means followed by the same letter do not differ by Tukey's test $(\mathrm{P}<0.05)$. ${ }^{1}$ According to numerical scale, where: $1=$ fully green fruits, up to $9=$ fully mature fruits. ${ }^{2}$ Values between 25 and 55 are considered appropriate, with 25 being associated with more acidic apples and 55 with sweeter apples. 


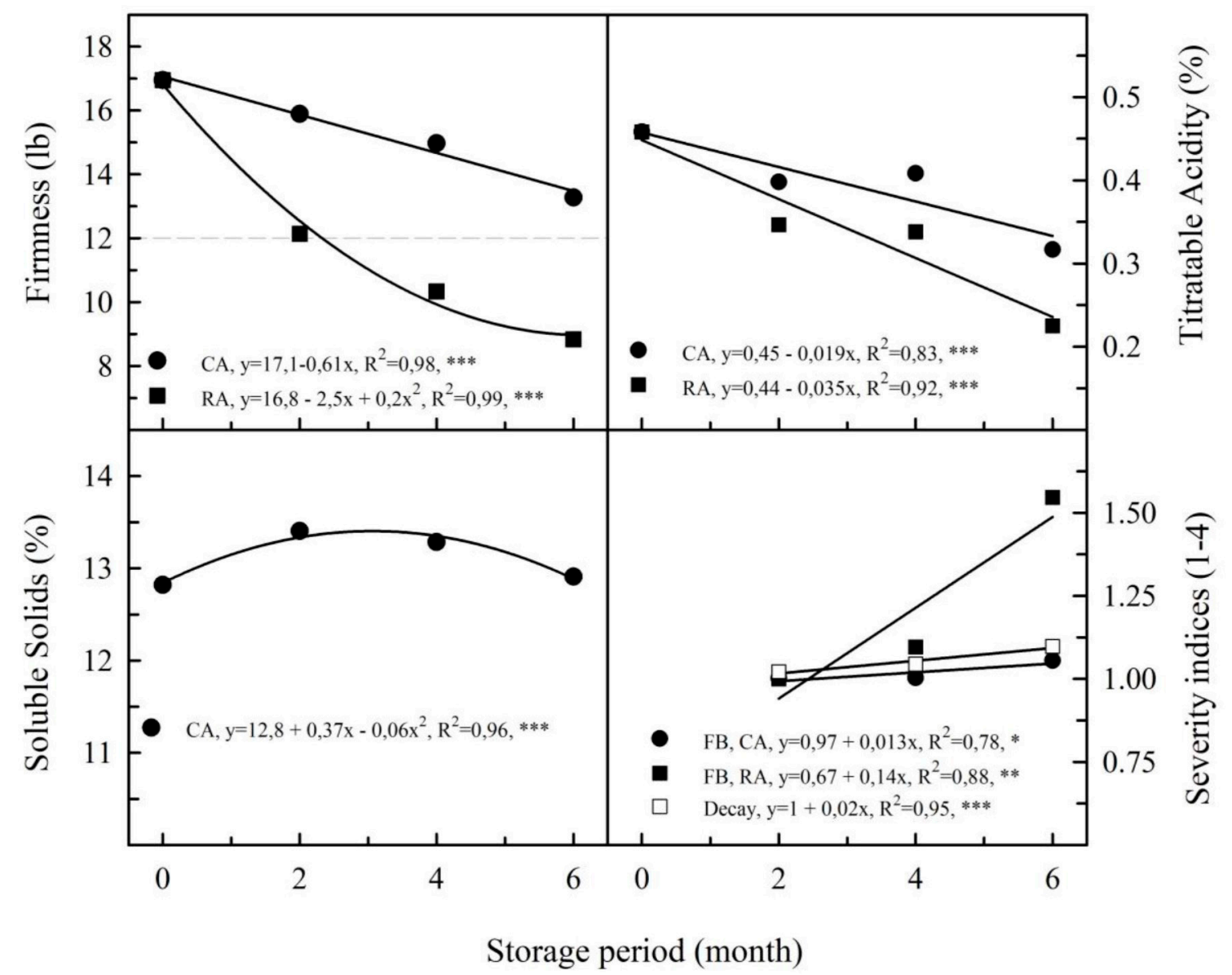

Figure 2. Average behavior of variables associated with storability of 'SCS425 Luiza' apples as a function of storage time and atmosphere (CA: Controlled Atmosphere, RA: Regular Air Atmosphere). FB = Flesh Browning. *,** Significant at 5 and $1 \%$ error probability, respectively.

We thank the Fischer Agrícola Fraiburgo Ltda Company for the logistical support in advanced field testing evaluations. To FAPESC - Foundation for Research Support in the State of Santa Catarina, and to ABPM Brazilian Association of Apple Growers, for financial support.

\section{References}

CNA - Confederação da Agricultura e Pecuária do Brasil. Hábitos de consumo de frutas, legumes e verduras no Brasil (FLVs). Brasília, 2011. Disponível em: $<\underline{\text { http:// }}$ www.cnabrasil.org.br/sites/default/files/pesquisas/ arquivos/pesquisa quantitativa fruticultura 1.pdf $>$.

DENARDI, F.; CAMILO, A.P.; KVITSCHAL, M.V. SCS417 Monalisa: cultivar de macieira com boa adaptação climática no Sul do Brasil e resistência múltipla a doenças e pragas. Revista Agropecuária Catarinense, Florianópolis, v.26, n.1, p.56-62, 2013.
FIORAVANÇO, J.C.; LAZZAROTTO, J.J. A cultura da macieira no Brasil: reflexões sobre produção, mercado e fatores determinantes da competitividade futura. Informações Econômicas, São Paulo, v.42, n.4, 2012.

FURLAN, C.R.C.; DANTAS, A.C.M.; DENARDI, F.; BECKER, W.F.; MANTOVANI, A. Resistência genética dos acessos do Banco de Germoplasma de Macieira da Epagri à mancha foliar de glomerella (Colletotrichum gloeosporioides). Revista Brasileira de Fruticultura, Jaboticabal, v.32, n.2, p. 507-514, 2010.

GONZÁlEZ, E.; SUTTON, T.B.; CORRELL, C.J. Clarification of the etiology of Glomerella Leaf Spot and Bitter Rot of apple caused by Colletotrichum spp. based on morphology and genetic, molecular, and pathogenicity tests. Phytopathology, Saint Paul, v.96, n.9, p.982-992, 2006.

HARKER, F.R.; GUNSON, F.A.; JAEGER, S.R. The case of fruit quality: an interpretative review of consumer attitudes and preferences for apples. Postharvest Biology and Technology, Amsterdam, v.28, n.3, p.333-347, 2003. 
HARKER, F.R.; KUPFERMAN,E.M.;MARIN,A.B.; GUNSON , F.A.; TRIGGS, C.M. Eating quality standards for apples based on consumer preferences. Postharvest Biology and Technology, Amsterdam, v.50, n.1, p.70-78, 2008 .

HARKER, F.R.; MAINDONALD, J.; MURRAY, S.H.; GUNSON, F.A.; HALLETT, I.C.; WALKER, S.B. Sensory interpretation of instrumental measurements 1: texture of apple fruit. Postharvest Biology and Technology, Amsterdam, v.24, n.1, p.225-239, 2002.

HAWERROTH, F.J.; PETRI, J.L.; LEITE, G.B.; HERTER, F.G. Brotação de gemas em macieiras 'Imperial Gala' e 'Fuji Suprema' pelo uso de Erger ${ }^{\circledR}$ e nitrato de cálcio. Revista Brasileira de Fruticultura, Jaboticabal, v.32, n.2, p.343-350. 2010.

HAWERROTH, M.C.; KVITSCHAL, M.V.; DENARDI, F.; VARGAS, K.C.; BRANCHER, T.L. Avaliação de genótipos de macieira utilizados como polinizadores da seleção M-15/07. Encontro Nacional sobre Fruticultura de Clima Temperado, 14. 2015, Fraiburgo. Resumos... Caçador: Epagri, 2015; v.2, p.152.

HEGEDÜS, A. Review of the self-incompatibility in apple (Malus $x$ domestica Borkh., syn.: Malus pumila Mill.). International Journal of Horticultural Science, Budapest, v.12, n.2, p.31-36, 2006.

KVITSCHAL, M.V.; DENARDI, F. Necessidade de diversificação de cultivares de macieira no Brasil. Revista Agropecuária Catarinense, Florianópolis, v.25, n.2, p.78-84, 2011.
KVITSCHAL, M.V.; DENARDI, F.; SCHUH, F.S.; MANENTI, D.C. Identificação de polinizadoras para a cultivar de macieira Daiane. Revista Brasileira de Fruticultura, Jaboticabal, v.35, n.1, p.9-14, 2013.

MAPA - Ministério da Agricultura, Pecuária e Abastecimento/ Secretaria de Política Agrícola. Maçã. Brasília, 2013. 7p. (Informativo, 54).

PETRI,J.L.;LEITE,G.B.; COUTO,M.;FRANCESCATTO, P. Avanços na cultura da macieira no Brasil. Revista Brasileira de Fruticultura, Jaboticabal, v.33, p.48-56, 2011. Volume especial.

SCOLARO, A.M.T.; ARGENTA, L.C.; AMARANTE, C.V.T.; PETRI, J.L.; HAWERROTH, F.J. Controle de maturação pré-colheita de maçãs 'Royal Gala' pela inibição da ação ou síntese do etileno. Revista Brasileira de Fruticultura, Jaboticabal, v.37, n.1, p.32-41, 2015.

VELHO, A.C.; ALANIZ, S.; CASANOVA, L.; MONDINO, P.; STADNIK, M.J New insights into the characterization of Colletotrichum species associated with apple diseases in southern Brazil and Uruguay. Fungal Biology, Amsterdam, v.119, p.229-244, 2015.

VIEIRA, L.M.; GOULART JUNIOR, R. Maçã - evolução do preço médio no atacado em Santa Catarina (em R\$/ cx 18 kg). Florianópolis: CEPA. 2014. 5p. (Boletim da Maçã, 1) 